\title{
ANALISIS FRAMING TERHADAP PEMBERITAAN KLUB SEPAK BOLA PERSEBAYA
}

\author{
Fikry Zahria Emeraldien', Aldi Purnomo², Nasario Wahyu Handoko ${ }^{3}$ \\ ${ }^{1,2,3}$ Program Studi Ilmu Komunikasi \\ Fakultas Ilmu Sosial dan Ilmu Politik, UPN "Veteran” Jawa Timur \\ e-mail: fikryzahria.ilkom@upnjatim.ac.id, aaldip7@gmail.com, \\ nasarioww@gmail.com
}

\begin{abstract}
Abstrak
Berita olahraga digemari masyarakat Indonesia, namun masih jarang diteliti. Untuk itu, penelitian ini bertujuan untuk mengetahui bagaimana perbedaan pemberitaan media cetak Jawa Pos dan Harian Surya dalammembingkai dan memberitakan klub sepakbola Persebaya Surabaya. Hal ini berkaitan dengan pasca peralihan media partner dari Jawa Pos ke Harian Surya. Dulu media partner Persebaya (2017) adalah Jawa Pos, di mana Presidennya, Azrul Ananda, merupakan CEO Jawa Pos. Namun, setelah Presiden Persebaya tersebut tidak berada di institusi Jawa Pos lagi, media partner Persebaya beralih menjadi Harian Surya.Penelitian ini menggunakan pendekatan analisis framingdengan metode kualitatif. Adapun model analisis framing yang digunakan adalah milik Zhongdang Pan dan Gerald M. Kosicky. Hasil yang didapatkan dari penelitian ini adalah bahwa pembingkaian berita oleh Jawa Pos dan Harian Surya memiliki perbedaan dalam pemberitaannya. Jawa Pos tidak memperlihatkan keberpihakan dalam pemberitaannya, sementara Surya sudah berusaha menyuguhkan berita yang berimbang meski kurang selaras dan kurang memenuhi kelengkapan unsur berita.
\end{abstract}

Kata-kata kunci: framing, sepak bola, media cetak, berita olahraga

\begin{abstract}
Sports news is popular with Indonesian people, but is still rarely studied. Becauseof this reason, this study aims to find out how the differences in the coverage of the print media of Jawa Pos and Harian Surya in framing and reporting on the Persebaya Surabaya football club. This relates to the displacement of media partners from Jawa Pos to Harian Surya. Previously, Persebaya's media partner was Jawa Pos (2017), where the President, Azrul Ananda, was the CEO of Jawa Pos. However, after the President of Persebaya was no longer in the Jawa Pos institution, Persebaya's media partner switched to Harian Surya. This study uses a framing analysis approach with qualitative methods. The framing analysis used is from Zhongdang Pan and Gerald M. Kosicky's model. The results obtained from this study are that the news framing by Jawa Pos and Harian Surya has differences in reporting.Jawa Pos does not show partiality in its reporting, while Surya has tried to present balanced news, although it lacks in harmony and less complete on the news elements.
\end{abstract}

Keywords : framing, football, print media, sports news 


\section{PENDAHULUAN}

Terdapat ungkapan yang sudah menjadi keyakinan sejarah dari waktu ke waktu: sport build character (Maksum, 2005; 2002). Kofi Anan, mantan Sekjen PBB pernah menyatakan: sport teaches life skill sport remains the best school of life (UnitedNation, 2003). United Nations melalui Task force on Sport for Development and Peace menyatakan bahwa olahraga merupakan instrumen yang efektif untuk mendidik kaum muda, terutama dalam hal nilai-nilai.

Dalam negara yang berkembang di Asia, Indonesia adalah negara yang mayoritas penduduknya memiliki antusiasmetinggi terhadap olahraga, terutama di bidang sepak bola. Namun, penelitian dalam bidang olahraga seperti sepak bola biasanya berkaitan dengan hal-hal praktis.Contohnya, seperti peneltian Pengaruh Metode Latihan Terhadap Peningkatan Passing dalam Permainan Sepak Bola oleh Tarju dan Wahidi (2017).

Sementara itu, banyak penelitian di Indonesia, khususnya analisis framing, lebih banyak menyoroti bidang politik dan hukum. Contohnya seperti Analisis Framing Pemberitaan Reuni Akbar oleh Fiorentina (2017). Padahal, berita olahraga pun banyak yang bisa dianalisa dan diteliti dengan analisis framing.Menurut Haryati (2017) olahraga dan media sangat erat hubungannya. Olahraga membutuhkan media dan media membutuhkan olahraga. Semua jenis olahraga memiliki kesempatan yang sama untuk dipublikasi.

Melihat fenomena tersebut, penelitian ini sangat menarik dilakukan untuk menganalisis perbedaan pemberitaan klub sepak bola Persebaya di dua media cetak. Sebab, Persebaya telah berpindah media partner dari Jawa
Pos ke Harian Surya pada tahun 2018 lalu.

Dalam perkembangannya, jurnalisme olahraga -mulai yang diterbitkan di media cetak hingga media online- memiliki berbagai macam cabang yang dapat dipublikasi. Menurut Hikmat dan Purnama Kusumaningrat (2007:13) bidang liputan wartawan olahraga sangat luas. Bidang liputan itu mencangkup sepak bola, basket, bulu tangkis, voli, dan lain-lain.

Adapun yang menjadi objek penelitian ini adalah pemberitaan tentang Persebaya. Persebaya adalah klub besar yang telah didirikan sejak tahun 1927. Klub ini telah banyak menggandeng partner untuk bekerja sama dalam memberitakan klub kebanggan arek-arek Suroboyo tersebut. Salah satunya adalah koran Jawa Pos.Pada tahun 2017, Azrul Ananda selaku pemilik Jawa Pos membeli 70 persen saham PT Persebaya Indonesia. Hal tersebut membuat Persebaya bekerjasama dengan Jawa Pos sebagai media partner untuk memberitakan Persebaya. Tetapi, pada tahun 2018, Persebaya secara resmi tidak berpartnerdengan Jawa Pos lagi. Hal itu berbarengan denganAzrul Ananda yang tidak lagi menjabat sebagai direktur utama Jawa Pos. Kemudian, Persebaya beralih ke Harian Surya sebagai media partner.

Harian Surya dan Jawa Pos merupakan media cetak yang memiliki citra yang baik di Jawa Timur.Di Surabaya dan sekitarnya, kedua media tersebut sangat terkenal. Masing-masing media cetak memiliki ideologi yang berbeda dalam hal pembingkaian beritanya sesuai kebutuhan perusahaan.

Persebaya resmi berganti media partner dari Jawa Pos ke Harian Surya. Hal tersebut dapat dilihat dari official website resmi Persebaya yang menunjukkan logo Harian Surya 
sebagai official partner. Hal ini menarik untuk diteliti karena dalam membingkai berita, masing-masing media akan memberitakan sekaligus mengostruksi sesuai dengan ideologi yang dimiliki. Untuk itu penelitian membandingkan berita di dua media cetak menggunakan analisis framing dengan model Zhongdang Pan dan Gerald M. Kosicky.

\section{TINJAUAN PUSTAKA}

Framing dapat berperan sebagai metode maupun teori. Modelanalisis yang digunakan adalah Zhongdang Pan dan Gerald M. Kosicky, karena model ini adalah model paling tajam untuk mengupas dan meneliti tentang analisis framing. Model ini cocok digunakan untuk menganalisa pesan dari media tertentu dalam mengonstruksi dan membingkai suatu teks berita.

Zhongdang Pan dan Kosicky telah merumuskan dalam teorinya, menurut mereka, framing adalah strategi atau cara untuk mengkonstruksi dan memproses berita. Perangkat kognisi yang digunakan dalam mengkode informasi, menafsirkan sebuah peristiwa yang dihubungkan dengan rutinitas dan konvensi dalam pembentukan makna. Zhongdang Pan dan Kosicky telah merumuskan, dalam modelnya, terdapat 2 hal, yaitu sosiologis dan psikologis. Dalam konsep psikologis, framing diartikan dengan struktur dan proses kognitif, karena menekankan bagaimana seseorang memproses informasi dalam dirinya. Sementara itu, secara sosiologis, framing berfungsi membuat suatu realitas menjadi teridentifikasi, dimengerti dan dipahami, karena di dalamnya sudah terdapat label tertentu.

Pan dan Kosicky mengartikan bahwa analisis framing merupakan sebuah proses membuat pesan yang lebih menonjol, menempatkan informasi lebih daripada yang lain sehingga khalayak lebih tertuju padapesan tersebut (Eriyanto dalam Surbakti 2013).

Dalam pendekatan Pan dan Kosiky, mereka membagi perangkat farming menjadi 4 bagian, yaitu sintaksis. Perangkat ini berhubungan dengan headline berita, lead berita, latar informasi, pernyataan, opini, kutipan, dan pengamatan atas peristiwa ke dalam bentuk susunan kalimat yang terbingkai di berita. Yang kedua adalah struktur skrip yaitu berhubungan dengan bagaimana cara wartawan dalam mengkisahkan berita dan mengemas berita. Yang ketiga adalah struktur tematik, hubungan antar kalimat yang membentuk teks berita secara keseluruhan. Yang keempat adalah struktur retoris, berhubungan dengan cara wartawan memakai dan memainkan susunan kata dalam berita yang diterbitkan. Struktur ini melihat bagaimana wartawan menggunakan pilihan kata, grafik, idiom, dan gambar bukan hanya untuk mendukung tulisan, tetapi juga menekankan arti tertentu kepada pembaca. Model Zhongdang Pan dan Gerald M Kosicky dapat digambarkan melalui tabel berikut: 
Tabel 1. Tabel Skema Pendekatan Analisis Framing Sumber: Eriyanto 2011

\begin{tabular}{|c|c|c|}
\hline Struktur & Perangkat Framing & Unit Yang Diamati \\
\hline $\begin{array}{l}\text { SINTAKSIS } \\
\text { Bagaimana cara wartawan } \\
\text { untuk menyusun berita. }\end{array}$ & 1. Skema berita & $\begin{array}{l}\text { Headline, lead, latar } \\
\text { informasi, kutipan, } \\
\text { sumber pernyataan, } \\
\text { penutup. }\end{array}$ \\
\hline \multicolumn{3}{|l|}{ SKRIP } \\
\hline $\begin{array}{l}\text { Bagaimana cara wartawan } \\
\text { untuk menyusun fakta. }\end{array}$ & 1. Kelengkapan berita & $5 \mathrm{~W}+1 \mathrm{H}$ \\
\hline $\begin{array}{l}\text { Bagaimana cara wartawan } \\
\text { menuliskan fakta. }\end{array}$ & $\begin{array}{l}\text { 1. Detail } \\
\text { 2. Koherensi } \\
\text { 3. Bentuk Kalimat } \\
\text { 4. Kata }\end{array}$ & $\begin{array}{l}\text { Paragraf, proporsi } \\
\text { kalimat, hubungan antar } \\
\text { kalimat }\end{array}$ \\
\hline $\begin{array}{c}\text { Bagaimana cara wartawan } \\
\text { menekankan fakta. }\end{array}$ & $\begin{array}{l}\text { 1. Leksikon } \\
\text { 2. Grafis } \\
\text { 3. Metafora }\end{array}$ & $\begin{array}{l}\text { Kata, idiom, } \\
\text { gambar/foto, grafik }\end{array}$ \\
\hline
\end{tabular}

Penelitian ini menggunakan media cetak sebagai sarana analisis framing terhadap pemberitaan klub sepak bola Persebaya Surabaya. Definisi media cetak adalah suatu media yang statis dan mengutamakan pesanpesan visual, media ini terdiri dari lembaran dengan sejumlah kata, gambar, atau foto, dalam tata warna dan halaman putih (Khazali, 1992).

Media cetak merupakan sarana bagi jurnalis untuk memberikan informasi bagi khalayak dalam bentuk foto, katakata, gambar, dan sebagainya. Media cetak sangat beragam ada majalah, tabloid, koran, dan surat kabar, tetapi disini peneliti menggunakan media cetak surat kabar/koran di Indonesia terbit dalam berbagai bentuk yang jenisnya tergantung kepada antara lain; frekwensi terbit, bentuk (tabloid atau bukan), kelas ekonomi pembaca (misalnya kita membandingkan antara harian Kompas dengan Pos Kota), peredarannya (skala nasional atau hanya daerah), serta penekananisinya (ekonomi, kriminal, agama atau umum,dan sebagainya). (Khazali, 1992)

\section{METODE PENELITIAN}

Penelitian ini menggunakan pendekatan kualitatif. Menurut Indriastuti (2018), pendekatan kualitatif tidak bermaksud untuk mengukur secara angka dan statistik melainkan memahami karakter dari fenomena tersebut. Pendekatan kualitatif merupakan antitesis atau lawan dari pendekatan kuantitatif. Pendekatan kualitatif ialah pendekatan yang di dalam usulan penelitian, proses, hipotesis, turun ke lapangan, analisis data dan kesimpulan data sampai denganpenulisannyamempergunakan aspek-aspek kecenderungan, non perhitungan numerik, situasional deskriptif, interview mendalam, analisis isi, bola salju, dan story. Pendektan kualitatif dipergunakan untuk menemukan atau mengembangkan teori 
yang sudah ada. Pendekatan kualitatif berusaha menjelaskan realitas dengan menggunakan penjelasan deskriptif dalam bentuk kalimat. Jika pendekatan kuatitatif bisa sangat terukur dan obyektif, maka pendekatankualitatif, keterukurannya sangat subyektif dan bisa diperdebatkan. (Pujileksono, 2015)

Jenis penelitian yang diambil merupakan penelitian deskripi yang memaparakan data atas uraian terhadap pembingkaian berita dan menggunakan media cetak Jawa Pos dan Harian Surya edisi Minggu, 01 September 2019. Peneliti mempelajari arti atau makna dari keterkaitan antarkalimat dalam penulisan berita.

Untuk penelitian kualitatif terhadap pesan media, banyak pendekatan dan analisis yang bisa digunakan. Cohtohnya, kita bisa menggunakan analisis semiotika dan framing. Semiotika, misalnya, digunakan dalam mempelajari representasi bromance dalam film Jawa (Hanani dan Reza, 2019). Sementara itu, framing dapat digunakan untuk meneliti bingkai pemberitaan Jawa Pos tentang Persebaya Junaedi, F. (2016).

Dalam penelitian ini, framing yang dipilih sebagai metode. Menurut Eriyanto (2002: 3) analisis framing adalah bagaimana media memahami dan memaknai realitas, dan dengan cara apa realitas itu di tindakan, inilah yang menjadi pusat perhatian dari analisis framing. Pengertian sederhana dari framing adalah pendekatan untuk mengetahui bagaimana perspektif atau cara pandang yang digunakan oleh wartawan ketika menseleksi isu dan menulis berita (Eriyanto, 2007:68 dalam Damayanti 2016).

\section{HASIL DAN PEMBAHASAN}

Penelitian ini menggunakan analisis framing yang termasuk ke dalam paradigma konstruksionis.
Paradigma ini mempunyai posisi dan pandangan tersendiri terhadap media dan teks berita yang dihasilkannya. Konep mengenai konstruksionime diperkenalkan oleh sosiolog interpretative, Peter L. Berger. Pendekatan ini mempunyai penilaian sendiri bagaimana media, wartawan, dan berita dilihat. Dalam pandangan konstruksionis, media dilihat sebaliknya. Media bukanlah sekadar saluran yang bebas, ia juga subjek yang mengkonstruksi realitas, lengkap dengan pandangan, bias, dan pemihakannya. Di sini media dipandang sebagai agen konstruksi sosial yang mendefinisikan realitas. Apa yang tersaji dalam berita, dan kita baca tiap hari, adalah produk dari pembentukan realitas oleh media. Media adalah agen yang secara aktif menafsirkan realitas untuk disajikan kepada khalayak (Eriyanto, 2011).

Data-data yang diperoleh dan dianalisis oleh peneliti menggunakan skema dan konsep model analisis Zhongdang Pan dan Gerald M. Kosicky, yang mengelompokkan ke dalam empat sub kategori yaitu, sintaksis (bagaimana cara wartawan menyusun berita), skrip (bagaimana cara wartawan untuk menyusun fakta), tematik (bagaimana cara wartawan menuliskan fakta), dan retoris (bagaimana cara wartawan menekankan fakta). Analisis ini digunakan untuk melihat bagaimana media cetak Jawa Pos dan Harian Surya membingkai dan memberitakan klub Persebaya, usai peralihan media partner Persebaya dari Jawa Pos ke Harian Surya. Peneliti menggunakan data penelitian media cetak koran Jawa Pos dan Harian Surya, dengan hasil dan pembahasan sebagai berikut:

\section{Sintaksis}

Pada bagian struktur sintaksis, koran Jawa Pos memberikan dua berita dan sudut pandang yang berbeda dalam 
pemberitaan klub sepak bola Persebaya Surabaya. Headline yang pertama berjudul "Gol David untuk Davi" dihalaman pertama.Berita ini memiliki leadyang menceritakan tentang David da Silva.Sementara itu,headline keduamereka memiliki judul "Pede Songsong Putaran Kedua", terletak di halaman pertamarubrikSportainment.

Kedua berita tersebut memiliki latar informasi yang informatif dan berkesinambungan. Pada berita yang pertama,Jawa Posmenuliskan kutipan dari David da Silva bahwa golnya adalah untuk anaknya yang saat ini tumbuh besar.Sementara itu, di berita kedua, terdapat 10 kutipan yang fokus pada keadaan Persebaya dan kedatangan pemain lama Persebaya dulu, David da Silva, yang saat ini direkrut kembali untuk membenahi keadaan Persebaya.

Jawa Pos menambahkan narasi "Optimisme menyongsong putaran kedua juga disampaikan Osvaldo Haay. Bahkan, dia yakin Persebaya bisa lebih baik daripada musim lalu". Kedua berita terebut ditutup dengan keberhasilan Persebaya pada berita satu dan hasil yang tidak memihak pada Bhayangkara pada berita dua.Ini menandakan bahwa Jawa Pos memiliki pemberitaan yang selaras dilihat dari judul dan isi beritanya.

Lebih lanjut lagi, Harian Surya memiliki headline dengan judul "Selebrasi David untuk Anak" dengan lead yang lebih membingkai bagaimana David da Silva melakukan selebrasi. Dalam latar informasi,Harian Surya justru memberitakan bagaimana Persebaya memenangkan pertandingan, dilampirkan pada halaman 15. Hal ini menunjukkan bahwa mereka kurang konsisten antara judul dan isi. Selain itu, sintaksis berita Surya ini dapat dimaknai pula bahwa Persebaya adalah klub yang kuat dan memang layak menang.
Dalam pemberitaannya, judul Surya fokus pada selebrasi David atas kemenangan Persebaya yang dipersembahkan untuk anaknya. Namun, apabila kita melihat lebih lanjut pada isi berita, rupanya Harian Surya tidak banyak membahas tentang hal di atas. Justru, mereka lebih banyak memasukkan kutipan langsungBejo Sugiantoro -pelatih sementara Persebaya pada saat itu- yang mengomentari tentang datangnya pelatih baru Persebaya Alfred Riedl yang akan menangani Persebaya dalam mengarungi putaran kedua Liga 12019. Total terdapattujuh kutipan Bejo dalam berita tersebut sedangkan kutipan David da Silva sendiri hanya dua. Padahal, judul berita mereka tentang David da Silva, tapi pembahasan tentang itu tidak lebih banyak dibandingkan dengan komentar Bejo.

Selain itu, terdapat pula komentar Yeyen Tumena, pelatih klub Bhayangkara FC, yang dimasukkan dalam berita.Harian Surya memasukkannya ke dalam bagian penutupan. Komentar tersebut tertulis sebagai berikut "Tapi mereka main dengan counter attack. Ini buat kami kecolongan saat asik menyerang".Iamengeluhkan pemainnya karena boros peluang di mulut gawang Persebaya, tidak seperti Persebaya yang bermain lebih efisien.

Dilihat dari struktur sintaksis, Jawa Pos dan Harian Surya memiliki pemberitaan yang berbeda. Jawa Pos memberitakan secara lebih konsisten dan linier dari segi headline, lead, latar informasi, kutipan, sumber pernyataan, dan penutup. Adapun headline, lead, dan isi berita Harian Surya kurang konsisten dan linier.

Penambahan kutipan dari pelatih lawan di atas memiliki makna bahwa Surya ingin menyuguhkan berita yang berimbang. Hal ini sangat penting, 
karena di dalam prinsip atau elemen jurnalisme, wartawan harus bisa menyuguhkan kebenaran (Kovach dalam Ishwara, 2011). Dengan kata lain, wartawan tidak boleh mengutamakan keberpihakan dan harus bisa meliputi semua obyek yang dia beritakan. Hal tersebut biasa dikenal dengan cover both sides.

Altschul dalam Surbakti (2013) mengatakan bahwa isi dari media mencerminkan kepentingan dari siapa yang membiayainya. Hal ini dapat terlihat dalam Harian Surya yang mana menunjukkan pemberitaan yang optimis terhadap Persebaya dalam headline-nya. Adapun Jawa Pos,meskipun media cetak tersebut sudah bukan merupakan media partner dari Persebaya, tetapi dia tetap membuat headline yang fair dan sesuai dengan apa yang terjadi. Dengan demikian, meskipun pemberitaan seringkali dikaitkan dengan kepentingan dari pemilik media, hal ini tidak nampak dalam pemberitaan Jawa Pos mengenai Persebaya kali ini.

\section{Skrip}

Untuk struktur skrip, Jawa Pos memenuhi unsur $5 \mathrm{~W}+1 \mathrm{H}$ yang merupakan syarat kelengkapan dalam penulisan berita.Semua unsur $5 \mathrm{~W}+1 \mathrm{H}$ tersebut dapat ditemukan pada pemberitaan tentang kemenangan Persebaya di Jawa Pos. Unsur $5 \mathrm{~W}+1 \mathrm{H}$ tersebut meliputi: (1) What: Persebaya pede songsong putaran kedua; (2) When: Sabtu, 31 Agustus 2019;(3)Where: pertandingan Persebaya melawan Bhayangkara FC di laksanakan di Stadion Patriot Candrabhaga, Bekasi; (4) Who: David da Silva, Bejo Sugiantoro; (5) Why: karena datangnya pemain lama Persabaya David da Silva yang menutup putaran pertama Liga 12019 dengan kemenangan (2-0) atas Bhayangkara FC; (6) How: kemenangan Persebaya tersebut diraih tanpa kehadiran empat pemain kunci, yaitu Ruben Sunadi, Irfan jaya, Hansamu Yama, dan Manuchekhr Dzhalilov.

Sementara itu, untuk skrip pemberitaan Persebaya di Harian Surya, meliputi: (1) What: Selebrasi David untuk anak; (2) When: 31 Agustus 2019; (3) Where: Stadion Patriot Candrabhaga, Bekasi; (4) Who: David da Silva, Bejo Sugiantoro, dan Yeyen Tumena; (5) Why: karena David da Silva mempersembahkan golnya untuk anaknya yang baru saja lahir. Sementara itu, peneliti kesusahan untuk menganalisis unsur how dalam berita ini. Sebab, judul berita ini adalah tentang selebrasi David da Silva. Akan tetapi, isinya tidak berkata demikian. Harian Surya lebih banyak membicarakan tentang jalannya pertandingan dan komentar-komentar pelatih Persebaya dan rivalnya, Bhayangkara FC.

Di dalam menuliskan berita, terutama di media cetak, kelengkapan isi berita adalah hal yang harus diperharikan. Dalam skrip, Zhongdang dan Kosicky memberlakukan analisis $5 \mathrm{~W}+1 \mathrm{H}$. Dalam kajian jurnalistik, $5 \mathrm{~W}+1 \mathrm{H}$ ini merupakan kelengkapan isi berita yang seyogyanya dipatuhi. Adanya pengurangan unsur berita, bisa jadi mengindikasi bahwa sebuah media sedang tidak objektif atau berpihak, yang mana hal tersebut tidak ditemukan dalam Jawa Pos. Sebab, mereka memberitakan Persebaya dengan unsur berita yang lengkap.Hal yang berbeda justru terlihat dalam Harian Surya. Berdasarkan pengamatan kami,kelengkapan isi berita mereka kurang terpenuhi. Juduldan isi berita juga akan lebih baik jika lebih linier sehingga tidakmembuat bingung pembaca.

Hal ini membuktikan bahwa sebagai mantan media partner, Jawa 
Pos tidak melakukan keberpihakan di dalam pemberitaan Persebaya. Mereka tidak mengurang-ngurangi unsur berita yang seharusnya disampaikan kepada pembaca, atau dengan kata lain Jawa Pos terbilang independen. Hal ini disebut oleh Devolder dalam Ishwara (2011) sebagai "obyektivitas yang subyektif", di mana "dari sebuah obyek muncul berbagai pandangan yang obyektif yang bersifat subyektif (karena didiungkapkan oleh seorang subyek)".

\section{Tematik}

Pemberitaan pertama Jawa Pos tentang Persebaya lebih fokus pada David da Silva yang telah memenangkan Persebaya 2-0 dengan Bhayangkara FC. Headline kedua mereka juga selaras dengan berita pertama. Akan tetapi, headline mereka yang ada di halaman utama Sportainment lebih banyak mengulas pelatih Persebaya yang baru, yaitu Alfred Riedl.Adapun hubungan antar kalimat yang ada dalam berita-berita tersebut selaras.

Pada Harian Surya, berita lebih ditekankan kepada bagaimana David da Silva, striker Persebaya, melakukan selebrasi.Meskipun judul mereka tentang selebrasi tersebut, namun fokus isi beritaadalah tentang bagaimanaPersebayamemenangkan pertandingan. Hal tersebut nampak pada proporsi kalimat yang digunakan. Kalimat terbanyak justru pada jalannya pertandingan yang berujung pada kemenangan Persebaya, bukan selebrasi David da Silva.

Jawa Pos dan Surya memang memiliki gaya yang berbeda dalam merangkai antarkalimat. Mereka juga memiliki tingkat koherensi yang berbeda dalam menyusun detil-detil pemberitaan. Namun, keduanya masih terbilang seirama. Kedua media memberitakan hal yang serupa, yaitu ide utamanya adalah mengenai kemenangan Persebaya dengan David da Silva sebagai pahlawan. Meski Jawa Pos lebih fokus pada pelatih dan Surya fokus pada jalannya pertandingan, keduanya bermuara pada hal yang sama, yaitu kemenangan Persebaya. Baik Jawa Pos maupun Surya tidak memiliki menunjukkan tendensi tertentu selain memberitakan tentang kemenangan klub tersebut. Dengan demikian, obyektivitas dilakukan oleh kedua pihak.

\section{Retoris}

Salah satu penekanan yang dilakukan oleh Jawa Pos terlihat dari foto yang dibidik oleh jurnalis di headline pertama.Foto itu menceritakan kegembiraan pemain Persebaya atas kemenangan yang dicetak oleh David Da Silva. Bidikan foto yang ada diberita kedua bisa dimaknaipermainan yang kasar atau bisa menimbulkan pelanggaran dari Bhayangkara FC. Di foto itu,bek Bhayangkara FC, Bagas Adi Nugroho, menarik baju Osvaldo Haay, salah seorang pemain Persebaya untuk menghentikan pergerakannya.Pada pemberitaan Harian Surya, terdapat penekanan kata "DAVID" yang menunjukan bahwa berita itu dimuat dengan membingkai selebrasi David da Silva, striker Persebaya yang merayakan golnya. Gambar yang dipotret pun juga menunjukkan tentang selebrasi David.

Foto-foto yang disuguhkan oleh Jawa Pos dan Persebaya memiliki penekanan yang berbeda. Jawa Pos lebih menonjolkan pada tegang dan serunya pertandingan. Adapun Surya lebih menonjolkan pada selebrasi David da Silva. Foto ini mendukung sintaksis pemberitaan Surya yang sedari awal terkesan membangun pesan tentang kebanggaannya akan Persebaya. Foto 
tersebut juga meneguhkan bahwa klub tersebut adalah klub yang kuat dan memang layak menang. Baik Jawa Pos maupun Surya sama-sama menampilkan foto-foto yang menunjukkan hybridity (Robertson dalam Emeraldien, 2018).

\section{SIMPULAN}

Dari analisis framing pada media cetak Jawa Pos dan Harian Surya mengenai pemberitaan tentang klub sepak bola Persebaya edisi 1 September 2019, dapat ditarikbeberapa kesimpulan, yaitu:

1. Pembingkaian berita oleh media cetak dilakukan dengan cara pemilihan sumber berita, kutipan, dan foto yang mendukung hal tersebut.

2. Jawa Pos dan Harian Surya memiliki perbedaan dalam pemberitaannya. Jawa Poscenderung memperlihatkan keselarasan antara headline,lead, dan isi berita,sementaraHarian Suryamasih kurang.

3. Meski sudah bukan media partner, Jawa Pos tidak melakukan pemberitaan yang tendensius. Dalam struktur sintaksis, skrip, tematis, dan retoris berita Persebaya, Jawa Pos dapat menunjukkan independensi dan ketidakberpihakan. Adapun Surya telah mencoba untuk melakukan pemberitaan yang berimbang, meski masih kurang dalam hal kelengkapan unsur berita.

\section{DAFTAR PUSTAKA}

Damayanti, S., Mayangsari, I. D., \& Putra, D. K. S. (2016). Analisis framing robert n. Entman atas pemberitaan reklamasi teluk jakarta di majalah tempo. eProceedings of Management, 3(3).
Devin, A. (2018). Peran Jurnalis Olahraga Pada Perkembangan Persepakbolaan Di Indonesia Periode 2015-2017 (Studi Pada Jurnalis Sepakbola Panditfootball.com) (Doctoral Dissertation, University Of Muhammadiyah Malang)

Emeraldien, F. Z. (2018). Culture in Glocalization Process: A Study of Indonesian Newspapers. Expose: Jurnal Ilmu Komunikasi, 1(2), 82-94.

Eriyanto, A. F. (2002). Konstruksi. Ideologi dan Politik Media, Yogyakarta: LKIS.

Fianto, L., \& Aminulloh, A. (2015). Analisis Framing Berita Kasus Korupsi Ketua Mahkamah Konstitusi Akil Mochtar di Vivanews. com dan Detik. com. JISIP: Jurnal Ilmu Sosial Dan Ilmu Politik, 3(1).

Fiorentina, R., Mayasari, M., \& Hariyanto, F. (2018). Analisis Framing Pemberitaan "Reuni Akbar 212"(Analisis Framing Model Robert N Entman Media Online kompas. com dengan republika. co. id Edisi 26 November 2017-9 Desember 2017). JURNAL POLITIKOM INDONESIANA, 3(2), 84-93.

Hagijanto, A. D. (2004). White Space dalam iklan di media cetak. Nirmana, 1(2).

HANANI, S. U., \& Reza, N. (2019). ARTIKEL BROMANCE REPRESENTATION IN JAVA CULTURE BACKGROUND MOVIE. Metakom, 51-63.

Haryati, T., Putra,R. B. A., \& Setyawati, H. (2018). Ananlisis Pemberitaan Olahraga pada 
Rubrik Gelora Harian Wawasan. JURNAL PENJAKORA, 4(2).

Indriastuti, Y. (2018). Keluarga Sebagai Katalis Peran Politisi Perempuan Jawa Timur. JURNAL ILMU KOMUNIKASI. 1(1).

Ishwara, L. (2011). Jurnalisme Dasar. Penerbit Buku Kompas.

Junaedi, F. (2016). Jawa Pos Membela Persebaya: Bingkai Pemberitaan Jawa Pos tentang Persebaya dalam Kongres PSSI 2016. ETTISAL Journal of Communication, 1(2), 208-225.

Pujileksono, S. (2015). Metode penelitian komunikasi kualitatif. Malang: $\quad$ Intrans Publishing.

Surbakti, L. J. R. (2013). Analisis Framing Pemberitaan Konflik Partai Nasional Demokratn (Nasdem) di Harian Media Indonesia dan Koran Sindo. Jurnal eKomunikasi, 1(2).

Tarju, T., \& Wahidi, R. (2017). Pengaruh Metode Latihan Terhadap Peningkatan Passing Dalam Permainan Sepak Bola. JUARA: Jurnal Olahraga, 2(2), 66-72. 